\title{
Development of Intrinsic and Synaptic Properties in a Forebrain Nucleus Essential to Avian Song Learning
}

\author{
Frederick S. Livingston and Richard Mooney \\ Department of Neurobiology, Duke University Medical Center, Durham, North Carolina 27710
}

In male zebra finches, the lateral magnocellular nucleus of the anterior neostriatum (LMAN) is necessary for the development of learned song but is not required for the production of acoustically stereotyped (crystallized) adult song. One hypothesis is that the physiological properties of LMAN neurons change over development and thus limit the ability of LMAN to affect song. To test this idea, we used in vitro intracellular recordings to characterize the intrinsic and synaptic properties of LMAN neurons in fledgling [posthatch days (PHD) 22-32] and juvenile zebra finches (PHD 40-51) when LMAN lesions disrupt normal song development, and in adults (>PHD 90) when LMAN lesions are without effect. In fledglings, depolarizing currents caused LMAN projection neurons to fire bursts of action potentials because of a putative low-threshold calcium spike (LTS). In contrast, juvenile and adult LMAN projection neurons fired accommodating trains of action potentials when depolarized but did not exhibit the burst mode of firing. Electrical stimulation of thalamic afferents elicited both monosynaptic EPSPs mediated by AMPA and NMDA receptors and polysynaptic IPSPs mediated by GABA $_{A}$ receptors from LMAN neurons at all ages studied here. In whole-cell voltage-clamp recordings, the EPSCs (NMDA-EPSCs) consisted of fast and slow components. Unlike juvenile and adult NMDA-EPSCs, those in fledglings were dominated by the slower component. Thus, both the intrinsic and synaptic properties of LMAN neurons change markedly during early song development (PHD 22-40) and achieve several adult-like properties during early sensorimotor learning and well before the time when LMAN lesions no longer disrupt song development.

Key words: LMAN; DLM; song nuclei; zebra finch; whole cell; intracellular recordings; NMDA receptors; AMPA receptors; low-threshold calcium spike; LTS; vocal plasticity; critical periods; song learning
The development and adult production of learned birdsong are controlled by a well defined CNS circuit known as the song system. Anterior forebrain nuclei, including the lateral magnocellular nucleus of the anterior neostriatum (LMAN), are essential to song development, but not to adult song production. As a first step toward understanding the developmentally restricted role of the anterior forebrain loop, we have investigated changes in the electrophysiological properties of LMAN neurons over the course of song learning.

Song learning begins with sensory acquisition, when the juvenile songbird first memorizes the song of another bird, and is followed by sensorimotor learning, when the bird matches its own vocalization to the memorized song via auditory feedback (Konishi, 1965; Price, 1979). Sensorimotor learning progresses from plastic song, which has a highly variable acoustical structure, to crystallized song, which possesses a high degree of acoustical stereotypy (Immelmann, 1969).

The production of learned song is controlled by serially linked forebrain structures that include nucleus $\mathrm{HVc}$ and the robust nucleus of the archistriatum (RA). RA neurons project both to

Received July 25, 1997; revised Sept. 12, 1997; accepted Sept. 17, 1997.

This research was supported by National Institutes of Health Grant 5T32GM08441 to F.S.L. and National Institutes of Health Grant DC02524 and a McKnight Foundation Award to R.M. We thank John Spiro, Stephanie White, Matt Kittelberger, Merri Rosen, Lori McMahon, Felix Schweizer, and two anonymous reviewers for providing thoughtful comments on earlier versions of this manuscript. We give special thanks to Rebecca Stacy for expert camera lucida reconstructions of LMAN neurons and to Michael Booze for skilled histology.

Correspondence should be addressed to Dr. Richard Mooney, Department of Neurobiology, Box 3209, Duke University Medical Center, Durham, NC 27710. E-mail: mooney@neuro.duke.edu

Copyright (C) 1997 Society for Neuroscience $\quad 0270-6474 / 97 / 178997-13 \$ 05.00 / 0$ the tracheosyringeal portion of the hypoglossal nucleus (nXIIts), which innervates the muscles of the avian song organ (syrinx), and to expiratory nuclei, including the nucleus ambiguus and nucleus retroambigualis (nAm/nRam; see Fig. 1) (Nottebohm et al., 1976, 1982; Wild, 1993). HVc and RA neurons exhibit increased activity during singing (McCasland, 1987; Yu et al., 1996), and lesioning these areas eliminates learned song while leaving unlearned vocalizations intact (Nottebohm et al., 1976; Simpson and Vicario, 1990). HVc and RA also are connected indirectly by the anterior forebrain pathway (AFP), which includes area $\mathrm{X}$, the medial nucleus of the dorsolateral thalamus (DLM), and LMAN (Okuhata and Saito, 1987; Bottjer et al., 1989). In zebra finches, LMAN lesions made at the height of sensorimotor learning produce a sudden and premature acoustical stereotypy that resembles crystallization (Bottjer et al., 1984; Scharff and Nottebohm, 1991), although similar lesions made in the adult zebra finch do not affect song production.

One hypothesis explaining the age-dependent effects of LMAN lesions is that LMAN neurons change physiologically during sensorimotor learning, thus gradually altering the capacity of LMAN to influence song quality. Two findings suggest that these changes involve synaptic transmission within LMAN. Dendritic spine frequency of LMAN projection neurons declines substantially between posthatch days (PHD) 21-100 (NixdorfBergweiler et al., 1995b), and NMDA receptors within LMAN are downregulated over the same period (Aamodt et al., 1992; Basham, 1996). This latter finding, along with the observation that the infusion of NMDA receptor antagonists into the anterior neostriatum during sensory acquisition reduces the number of copied notes (Basham et al., 1996), suggests that these synaptic 

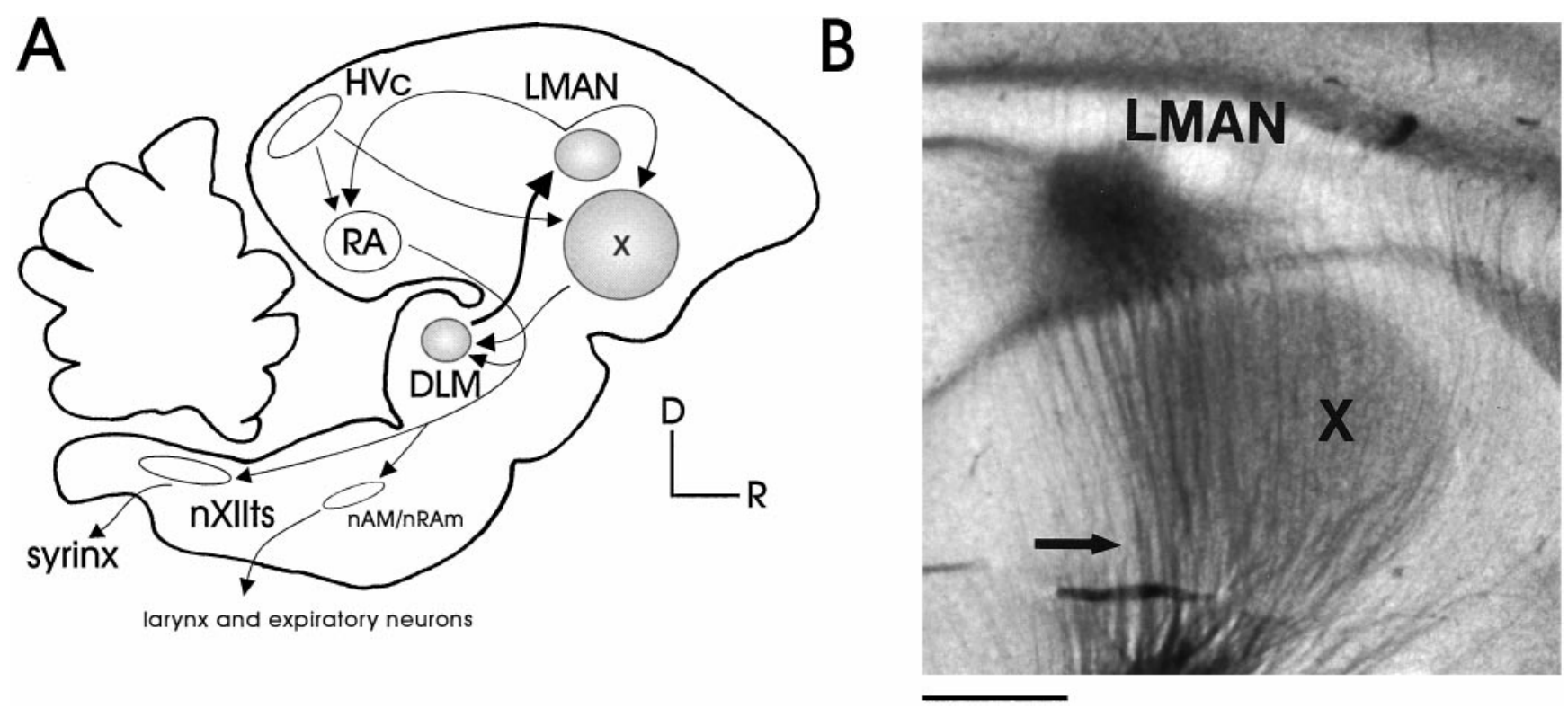

Figure 1. The song system. A, Simplified schematic of the song system. The motor pathway (open structures) is essential for the production of learned song and includes the nuclei $H V c, R A, n A m / n R A m$, and $n X I I t s$. The anterior forebrain pathway (AFP; shaded structures) is critical for normal song development and contains $X, D L M$, and $L M A N(D$, dorsal; $R$, rostral). $H V c$, Used here as the proper name, also known as the higher vocal center; $R A$, robust nucleus of the archistriatum; $n A m$, nucleus ambiguus; $n R A m$, nucleus retroambigualis; $n X I I t s$, tracheosyringeal portion of the hypoglossal nucleus; $X$, area $\mathrm{X}$ of the lobus parolfactorius; $D L M$, medial nucleus of the dorsolateral thalamus; $L M A N$, lateral portion of the magnocellular nucleus of the anterior neostriatum. $B, \mathrm{LMAN}$ and area $\mathrm{X}$ in a transilluminated parasagittal living brain slice, showing the ascending thalamic fibers from DLM (arrow). Scale bar, $800 \mu \mathrm{m}$.

changes involve the NMDA receptor. Therefore, establishing whether NMDA receptor-mediated synaptic currents in LMAN change during development is essential, especially because NMDA receptor-mediated currents at other synapses change as sensitive periods close (Carmignoto and Vicini, 1992; Hestrin, 1992; Ramoa and McCormick, 1994; Crair and Malenka, 1995). Thus, we have characterized the intrinsic and synaptic properties of adult ( $>$ PHD 90) male zebra finch LMAN neurons by using in vitro intracellular recordings and then have compared these properties with those from younger birds at either the beginning (PHD 22-32) or height (PHD 40-51) of sensorimotor learning.

\section{MATERIALS AND METHODS}

Experiments were performed with brain slices made from male zebra finches in accordance with a protocol approved by the Duke University Institutional Animal Care and Use Committee. Finches used in these experiments ranged in age from 22-180 PHD and were obtained from our breeding colony, which consisted of individually caged mating pairs and their offspring less than PHD 50 and group holding cages that contained birds older than PHD 50. In this setting, birds were not acoustically or visually isolated from each other. The three age groups used for these studies were between PHD 22-32, 40-51, and older than 90. These ages were chosen because PHD 22-32 are at the onset of sensory acquisition in zebra finches but in large part predate the beginning of song production (Immelmann, 1969; Arnold, 1975). Sonographic analysis indicates that, in our colony, birds between PHD 40-51 are in the early stages of sensorimotor learning (and possibly still in the later phases of sensory acquisition; for review, see Slater et al., 1988). This middle age range is the period when LMAN lesions also exert their most deleterious effects on song development (Bottjer et al., 1984). In contrast, birds greater than PHD 90 in our colony sing stable song, and, at this age, LMAN lesions do not affect song quality in male zebra finches (Bottjer et al., 1984; Scharff and Nottebohm, 1991).

The slice preparation procedure has been described previously in detail (Mooney and Konishi, 1991). Briefly, the bird was decapitated after ketamine injection and Metofane inhalation anesthesia (for some whole-cell experiments, ketamine was omitted, but the presence or absence of ketamine in the anesthetic regimen did not alter NMDA receptor-mediated currents). The brain was removed and chilled in artificial CSF (ACSF; $4^{\circ} \mathrm{C}$ ) and then cut sagittally along the bifurcation of the midsagittal sinus. Sagittal slices that included LMAN were cut at $400 \mu \mathrm{m}$ thickness on a vibratome (Vibratome Series 1000, Ted Pella, Redding, CA) and immediately transferred to an interface-type holding chamber maintained at room temperature. After 60-90 min, slices were transferred either to an interface-type chamber $\left(30^{\circ} \mathrm{C}\right.$; Medical Systems, Greenvale, NY) for sharp microelectrode intracellular recordings or to a superfusion chamber $\left(24^{\circ} \mathrm{C}\right)$ for whole-cell recordings. The ACSF perfusate was equilibrated with $95 \% \mathrm{O}_{2} / 5 \% \mathrm{CO}_{2}$. LMAN and the DLM axons ascending to LMAN were readily visualized under transillumination (Fig. 1B).

ACSF consisted of (in mM) $119 \mathrm{NaCl}, 2.5 \mathrm{KCl}, 1.3 \mathrm{MgCl}_{2}, 2.5 \mathrm{CaCl}_{2}$, $1 \mathrm{NaH}_{2} \mathrm{PO}_{4}, 26.2 \mathrm{NaHCO}_{3}$, and 11 glucose. Equiosmolar sucrose was substituted for $\mathrm{NaCl}$ during the tissue preparation stage.

Electrophysiological recordings. Stable sharp intracellular recordings (112 cells in 105 slices from 50 animals), which were classified as those in which the membrane potential of a cell was negative of $-60 \mathrm{mV}$ for a period of 15 or more minutes, were obtained in brain slices made from male zebra finches throughout song development (PHD 22-180). Sharp intracellular recordings were made with borosilicate glass pipettes (BF100-50-10, Sutter Instrument, Novato, CA) pulled to a final resistance of $60-120 \mathrm{M} \Omega$ and filled with $3 \mathrm{M} \mathrm{K}$-acetate. The electrodes were advanced through the slice with a Newport Series 360 Motorizer (Newport Instruments, Fountain Valley, CA), which replaced the fine $z$-axis micrometer on a Marzhauser MM-33 micromanipulator (Sutter Instrument). Intracellular potentials were amplified with an Axoclamp 2B amplifier (Axon Instruments, Foster City, CA) in bridge mode, low-passfiltered at $1-3 \mathrm{kHz}$, and digitized at $10 \mathrm{kHz}$.

Whole-cell recordings (39 cells in 34 slices from 24 animals) were obtained in brain slices made from male zebra finches throughout song development (PHD 22-180). These recordings were made with borosilicate patch pipettes (3-7 M $\Omega$ ) coupled to a three-dimensional hydraulic micromanipulator (Newport Instruments) mated to a mechanical positioner (MX110 Siskiyou Design, Soma Scientific Instruments, Irvine, $\mathrm{CA}$ ). Pipettes were filled with an internal solution consisting of (in $\mathrm{mM}$ ) $100 \mathrm{Cs}^{+}$-gluconate, 10 EGTA, $5 \mathrm{MgCl}_{2}$, $40 \mathrm{HEPES}, 2 \mathrm{Na}^{+}$-ATP, 0.3 $\mathrm{Na}^{+}$-GTP, and $1 \mathrm{QX}-314$; the $\mathrm{pH}$ was adjusted to 7.25 with $\mathrm{CsOH}(50 \%$ $\mathrm{gm} / \mathrm{ml} \mathrm{H}_{2} \mathrm{O}$ ). Whole-cell currents were recorded with an Axopatch 1D intracellular amplifier (Axon Instruments), and current traces were dig- 
itized at $10 \mathrm{kHz}$ after low-pass filtering at $1-5 \mathrm{kHz}$. Series resistance was monitored throughout the recording by measuring the current transients resulting from small $(2 \mathrm{mV})$ hyperpolarizing voltage pulses. Holding potentials were not corrected for the liquid junction potential.

Bipolar stimulating electrodes either were made from individual tungsten microelectrodes (Micro Probe, Clarksburg, MD) or were prefabricated concentric bipolar electrodes (FHC, Brunswick, ME). To stimulate the DLM-LMAN synapse while avoiding accidental activation of LMAN axon collaterals in area $\mathrm{X}$, we placed stimulating electrodes in regions ventral and caudal to area $\mathrm{X}$. We elicited synaptic responses at $0.1 \mathrm{~Hz}$ by applying a brief $(100 \mu \mathrm{sec})$ electrical stimulus $(50-650 \mu \mathrm{A})$ to the DLM axons. The stimulation protocol used here activated DLM axons, because these are the only known source of afferent input to LMAN and because stimulating electrodes were placed in the region where DLM axons travel to reach their target (Bottjer et al., 1989).

Data acquisition and analysis. Data acquisition and analysis for intracellular recordings were performed with a National Instruments (Austin, TX) data acquisition board (AT-MIO-16E2), controlled by custom LabVIEW software written by Fred Livingston and Rob Neummann. Subthreshold responses were measured with hyperpolarizing current pulses (1-2 sec; from -200 to -400 pA). Suprathreshold responses (i.e., those that generated action potentials) were measured in response to depolarizing current pulses (1-2 sec, from +100 to $+800 \mathrm{pA})$. Input resistance measurements, calculated by measuring the steady-state voltage caused by injecting small ( $-200 \mathrm{pA})$ hyperpolarizing current pulses, were made throughout the recording session; reported values were measured within the first $30 \mathrm{~min}$ of a recording session. Membrane potential was measured during the first and last few minutes of a recording session; then an average of these two values was obtained after subtracting the membrane potential offset (determined after exiting the cell) from the latter value. Average firing rates were measured in response to 1- to 2-sec-long depolarizing currents. AHPs after a current pulse were identified as excursions of the membrane potential that traveled negative of the prestimulus baseline. Synaptic currents and potentials shown here are the averages of three to nine individual events, unless otherwise specified.

NMDA receptor-mediated EPSCs were recorded in $2.5 \mu \mathrm{M} \mathrm{NBQX}$ and $50 \mu \mathrm{M}$ picrotoxin and were evoked while the membrane potential was held $20 \mathrm{mV}$ more positive than the empirically determined EPSC reversal potential $\left(E_{\mathrm{rev}}\right)$ to remove the voltage-dependent blockade by extracellular magnesium (Mayer et al., 1984; Nowak et al., 1984). Decay time constants of NMDA receptor-mediated EPSCs were estimated by fitting the falling phase of the current with a double-exponential decay function, $y=y_{0}+\mathrm{A}_{1} \mathrm{e}^{-\left(x-x_{0}\right) / \tau_{1}}+\mathrm{A}_{2} \mathrm{e}^{-\left(x-x_{0}\right) / \tau_{2}}$, constrained to baseline (Origin, Microcal Software, Northampton, MA); double-exponential fits of the NMDA EPSCs always provided lower $\chi^{2}$ values than did singleexponential fits. These double-exponential fits yielded four variables: a time constant $\left(\tau_{1}\right)$ and its relative amplitude $\left(\mathrm{A}_{1}\right)$ for a fast component, and a time constant $\left(\tau_{2}\right)$ and its relative amplitude $\left(\mathrm{A}_{2}\right)$ for a slow component. The percentage of the slow component was calculated by the equation $\left(A_{2} /\left(A_{1}+A_{2}\right)\right) \cdot 100$. EPSC rise times were calculated as the time between 10 and $90 \%$ of the peak amplitude. One-way ANOVAs and two-tailed Student's $t$ tests (Origin) were used to test for significance; the results of these analyses are reported in the tables and the figure legends.

Drug application. During interface recordings, drugs were applied from a puffer pipette manufactured from $1.5 \mathrm{~mm}$ borosilicate glass, pulled to a tip diameter of 20-50 $\mu \mathrm{m}$, and loaded with the drug dissolved in ACSF. The pipette was coupled to a Picospritzer (General Valve, Fairfield, NJ), which was used to eject a small drop of the drug onto the slice. Drug concentrations were D-APV (D(-)-2-amino-5-phosphonopentanoic acid), $\quad 400-800 \quad \mu \mathrm{M}$; NBQX (1,2,3,4-tetrahydro-6-nitro-2,3-dioxobenzo $(f)$ quinoxaline-7-sulfonamide disodium), 25-50 $\mu \mathrm{M}$; picrotoxin, $200 \mu \mathrm{M}$; and $\mathrm{NiSO}_{4}\left(\mathrm{NH}_{4}\right)_{2} \mathrm{SO}_{3}, 10 \mathrm{~mm}$. The actual concentration of the drug at the recording site was assumed to be substantially lower. Drug application for whole-cell experiments was accomplished by bath perfusion of the drug. In these experiments the bath (i.e., final) concentrations of drugs were D-APV, 50-100 $\mu \mathrm{M}$; NBQX, 2.5-5 $\mu \mathrm{M}$; and picrotoxin, $50 \mu \mathrm{M}$.

Histology of LMAN neurons. Neurobiotin (4-6\% for sharp microelectrodes and $0.5 \%$ for whole-cell pipettes) was used for all intracellular recordings. Depolarizing currents $(+0.5-1.5 \mathrm{nA}, 1 \mathrm{sec}$ in duration at 2 sec intervals) were applied for 15-20 min at the end of each recording session. Then the slice was fixed in $4 \%$ paraformaldehyde in $25 \mathrm{~mm}$ sodium phosphate buffer for $12-16 \mathrm{hr}$ at $4^{\circ} \mathrm{C}$, resectioned on a freezing microtome at $75 \mu \mathrm{m}$, and visualized with avidin-HRP (diluted 1:100; Vector Laboratories, Burlingame, CA) and 3'3'-diaminobenzidine tetra- hydrochloride; the reaction was intensified with $1 \% \mathrm{CoCl}_{2}$ and $1 \%$ $\mathrm{NiSO}_{4}\left(\mathrm{NH}_{4}\right)_{2} \mathrm{SO}_{3}$. Camera lucida drawings were made on a Zeiss microscope (Oberkochen, Germany), using a $63 \times$ objective. After reconstruction, sections were counterstained (cresyl violet) to confirm that cells were located within the boundaries of the nucleus.

Reagents. All reagents for ACSF were obtained from Mallinckrodt Specialty Chemical (Paris, KY); D-gluconic acid and picrotoxin were from Sigma (St. Louis, MO); $\mathrm{CsOH}$ was from Aldrich Chemical (Milwaukee, WI); $\mathrm{NiSO}_{4}\left(\mathrm{NH}_{4}\right)_{2} \mathrm{SO}_{3}$ was from Fisher Scientific (Pittsburgh, $\mathrm{PA})$; all other drugs were obtained from Research Biochemicals International (Natick, MA).

\section{RESULTS}

Sharp microelectrode recordings initially were used to characterize the intrinsic and synaptic properties of LMAN neurons, because this technique was most reliable for obtaining stable recordings in zebra finch tissue of all ages. In addition, whole-cell voltage-clamp recordings were used to characterize more completely evoked synaptic currents without the confounding effects of active conductances in the postsynaptic cell. Of 112 LMAN neurons studied with sharp microelectrodes, 80 were from adults, 16 were from juveniles, and 16 were from fledglings. Of the 39 cells studied using whole-cell pipettes, 13 were from adults, 8 were from juveniles, and 18 were from fledglings.

Neurobiotin staining revealed that almost all (75 of 80 ) of the LMAN neurons from which there were recordings had spinous dendrites and a main projection axon that divided into two branches; one of the branches traveled ventrally toward area X, while the other branch exited LMAN caudally in the tract that contains LMAN axons projecting to RA (Figs. $2 A, 4 A$ ). At a much lower frequency ( 5 of 80 cells), we also encountered a class of smaller neurons with thin dendrites that we tentatively identified as interneurons, but these were not included in any further analysis.

\section{Intrinsic properties}

Adult LMAN projection neurons had an average resting potential of $-76 \pm 1 \mathrm{mV}$ (mean \pm SEM) and an average input resistance of $90 \pm 4 \mathrm{M} \Omega$ (Table 1). Depolarizing current pulses could produce trains of action potentials that accommodated over the period of the applied pulse (Fig. $2 B$ ), and the relationship between instantaneous spike frequency and spike interval number was fit by a straight line (Fig. $2 C$ ). In addition, the average firing rate of these action potential trains increased in a linear manner over the range of current pulses routinely applied (Fig. 3). Afterhyperpolarizations (AHP) following spike trains were observed in some cells (Fig. $5 A$, Table 1 ), and an inward rectification component often was observed (Table 1 ) in response to hyperpolarizing current pulses (asterisk in Fig. 2B; see also Table 1).

The intrinsic properties of juvenile LMAN projection neurons were quite similar to those of adults. The average resting membrane potential of juvenile neurons was $-76 \pm 2 \mathrm{mV}$, and the average input resistance was $98 \pm 9$ (Table 1). As in the adults, the spike trains evoked by depolarizing currents underwent accommodation, such that the relationship between instantaneous spike frequency and spike interval number was best fit by a straight line (see legend in Fig. 2). In addition, the average firing rate of these action potential trains increased in a linear manner over the range of applied depolarizing current pulses (Fig. 3). Inward rectification was exhibited in juvenile neurons in response to hyperpolarizing current pulses, and AHPs also were often observed in these cells (Table 1). Finally, one LMAN neuron recorded from animals in this age group had suprathreshold firing properties like those described for fledgling neurons (see below). 



Figure 2. The morphology and subthreshold and suprathreshold responses of an adult LMAN projection neuron. $A$, Camera lucida reconstruction of a neurobiotin-stained neuron of the type encountered in this study. LMAN projection neurons have spinous dendrites, local collaterals, and a bifurcated primary axon, with one process traveling caudally toward RA and the other ventrally toward area X (dashed lines represent missing portions of axons). The inset on the right is a low-power camera lucida reconstruction showing the same LMAN neuron in its relation to the borders of LMAN and area X (dorsal is toward the upper right, and rostral is toward the lower right). Scale bar, $20 \mu \mathrm{m} ; 200 \mu \mathrm{m}$ for inset. B. Adult LMAN neurons typically fired action potential trains that accommodated in response to depolarizing currents, as shown in the top two traces. Inward rectification (marked by an asterisk) often occurred in response to the larger hyperpolarizing currents, as shown in the third set of traces. Resting potential $=76 \mathrm{mV}$. $C$, The instantaneous firing frequency is shown plotted as a function of the spike interval number and is well fit by a straight line [average correlation coefficient for the adult population, in response to $+600 \mathrm{pA}$, was $r=-0.93 \pm 0.01(n=39)]$. The average correlation coefficient for the juvenile population, in response to +600 pA, was $r=$ $-0.86 \pm 0.03(n=12)$.

Fledgling LMAN neurons were not significantly different from juvenile and adult cells in their resting potentials $(-77 \pm 2 \mathrm{mV})$ and input resistances $(85 \pm 7 \mathrm{M} \Omega$; see Table 1 for statistical comparisons). In direct contrast to the adult and juvenile neurons, however, individual fledgling LMAN projection neurons (Fig. $4 A$ ) often fired in a bursting mode in response to depolarizing currents (mode 1; 12 of 15 cells; Figs. $4 B$ ). Of the 12 fledgling LMAN neurons that displayed the bursting mode, eight cells fired in this mode when depolarized from the actual resting potential. In the other four cells the bursting mode appeared only when the depolarizing pulses were preceded by tonic hyperpolar- ization (Fig. 5A). Regardless, depolarization-induced bursting was enhanced by previous hyperpolarization (Fig. $5 B$ ).

Fledgling LMAN neurons also could fire in a mode that was similar to those seen at older ages (mode 2; 9 of 15 cells; Fig. $4 B$ ). In addition to the four cells that could be transformed from mode 2 to mode 1 by previous hyperpolarization, three cells fired only in mode 2 throughout the recording, whereas two other cells spontaneously switched between the two firing modes (see, for example, Fig. 4B). In mode 2, the instantaneous firing frequency was a linear function of the interspike interval (Fig. $4 C$ ), and the average spike frequency increased in a linear manner with respect 


\begin{tabular}{llll} 
& & & \\
& $\begin{array}{l}\text { Fledgling: } 27-32 \text { PHD } \\
\text { (mean }=30, n=16 \text { cells } \\
\text { from } 15 \text { slices) }\end{array}$ & $\begin{array}{l}\text { Juvenile: } 40-51 \text { PHD } \\
\text { (mean }=43, n=16 \text { cells } \\
\text { from } 16 \text { slices) }\end{array}$ & $\begin{array}{l}\text { PHD }(\mathrm{mean}=180 \\
n=75 \text { cells from }\end{array}$ \\
Parameter & $-77 \pm 2, n=12$ & $-76 \pm 2, n=16$ & $-76 \pm 1, n=59$ \\
\hline$V_{\text {rest }}(\mathrm{mV} \pm \mathrm{SEM})^{a}$ & $82 \pm 8, n=13$ & $98 \pm 9, n=16$ & $90 \pm 4, n=59$ \\
Input resistance $(\mathrm{M} \Omega \pm \mathrm{SEM})^{b}$ & $\mathrm{Y}$ & $\mathrm{Y}$ & $\mathrm{Y}$ \\
Accommodation $(\mathrm{Y} / \mathrm{N})$ & $80 \%(12 / 15)$ & $7 \%(1 / 15)$ & $0 \%(0 / 69)$ \\
Bursting cells & $50 \%(8 / 16)$ & $60 \%(9 / 15)$ & $33 \%(19 / 58)$ \\
AHP & $70 \%(7 / 10 ; 6 \mathrm{nd})$ & $89 \%(8 / 9 ; 6 \mathrm{nd})$ & $64 \%(29 / 45)$ \\
Inward rectification & & & \\
\hline
\end{tabular}

$\mathrm{nd}=$ not determined.

One-way ANOVAs: ${ }^{a} F=0.02, p>0.97 ;{ }^{b} F=1.1, p>0.33$.

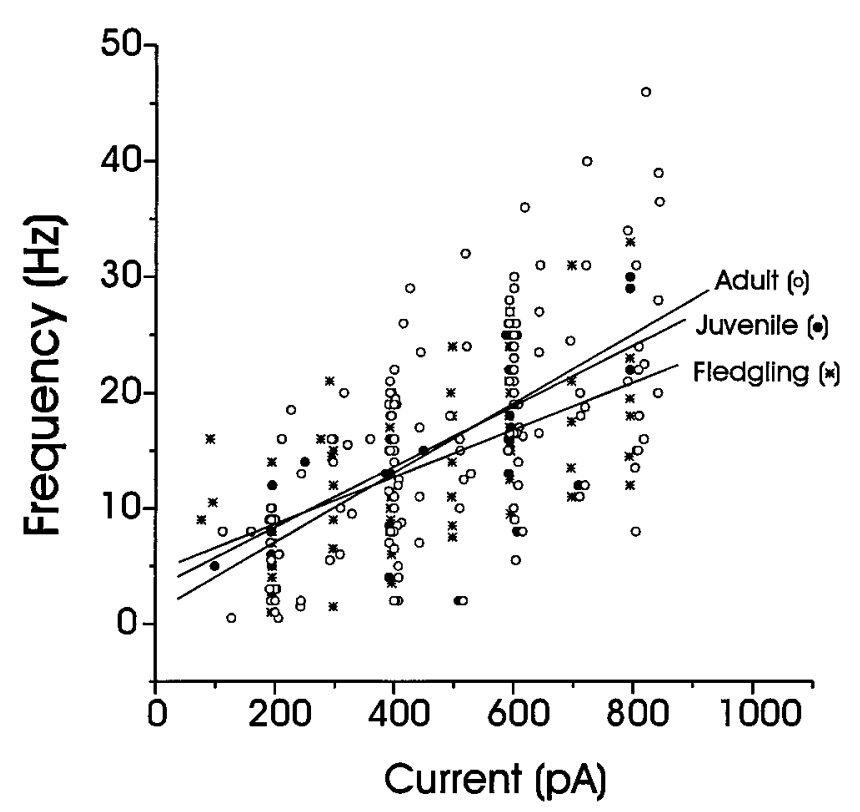

Figure 3. Average action potential firing frequencies for different depolarizing currents (1-2 sec in duration) from LMAN neurons of various ages. The average action potential firing frequencies were calculated for fledgling (stars; $n=15$ ), juvenile ( filled circles; $n=14$ ), and adult (open circle $n=55$ ) LMAN neurons and were plotted as a function of the injected current. Linear fits of the data from each age are shown; the firing rate in response to a given amount of injected current did not differ among the age groups. One-way ANOVAs demonstrated that the responses were not significantly different across ages at $+200 \mathrm{pA}(F=0.2, p>0.8),+400$ $\mathrm{pA}(F=0.5, p>0.6)$, and $+600 \mathrm{pA}(F=0.5, p>0.6)$.

to the injected current amplitude as seen in juveniles and adults (Fig. 3; see figure legend for statistical comparison). In summary, individual fledgling LMAN projection neurons could exhibit two distinct modes of firing in response to depolarizing currents, including a bursting mode that was never observed in adult LMAN neurons at normal resting potentials ( $n=60$ cells) or after previous hyperpolarization $(n=9$ cells).

We sought to clarify the ionic basis of the mode 1 action potential firing, which resembles a bursting behavior that has been observed in other cell types (see Discussion). Because nickel is known to block such bursting behavior (Fox et al., 1987), we applied nickel (10 $\mathrm{mm}$ ) directly to LMAN via a puffer pipette. Nickel application reversibly blocked the bursting component of the response to suprathreshold depolarizing currents while leaving the cell with its ability to fire action potentials intact (Fig. 6; five of five cells were blocked, three with at least partial recovery). In the presence of nickel, fledgling LMAN neurons that previously had fired in mode 1 now exclusively exhibited mode 2 action potential discharges. The enhancing effects of previous hyperpolarization and the blocking effects of nickel strongly suggest that a low-threshold calcium spike (LTS) contributes to the action potential bursting that we have seen in fledgling LMAN projection neurons.

\section{Synaptic properties}

To investigate the functional properties of the synapse between DLM axons and LMAN neurons, we evoked synaptic responses from LMAN projection neurons by electrically stimulating ascending thalamic axons in brain slices prepared from animals PHD 22-180. Initial experiments were performed with sharp microelectrodes to record postsynaptic potentials (PSPs) elicited within LMAN by thalamic fiber stimulation. Subsequent experiments used the superior voltage control afforded by the whole-cell technique to establish the contribution of NMDA receptors to the evoked synaptic current and to determine whether the kinetics of these NMDA receptor-mediated currents change over the course of development.

Electrical stimulation of DLM axons routinely elicited PSPs from LMAN projection neurons at all ages. At lower stimulus intensities, these responses consisted of a short-latency monotonic PSP that was depolarizing (Fig. 7). Because this PSP could drive the cell to spike if the postsynaptic membrane was sufficiently depolarized (data not shown), it was classified as an EPSP. In most cells, higher stimulus strengths could elicit the shortlatency EPSP and also a longer-latency hyperpolarizing component, which was classified as an IPSP (marked by an asterisk in Fig. 7). This IPSP grew in amplitude as the stimulus intensity was increased (Fig. 7).

To determine the contribution of postsynaptic glutamate receptors to the EPSPs elicited within LMAN by stimulating thalamic fibers at lower intensities, we focally applied glutamate receptor antagonists directly to LMAN with a puffer pipette. In slices prepared from adult and juvenile birds, the application of the AMPA receptor antagonist NBQX (25 $\mu \mathrm{M})$ reversibly blocked the EPSP elicited by stimulating thalamic fibers (Fig. 8, Table 2). In the presence of NBQX, a smaller, slower EPSP, reminiscent of NMDA receptor-mediated EPSPs, often was observed (trace 2, Fig. 8). Consistent with this view, the NMDA receptor antagonist D-APV could depress longer-latency components of the EPSP $(\sim 10-20$ msec after stimulus; compare traces $3 \& 4$, Fig. 8; see also Table 2). These results suggest that both 

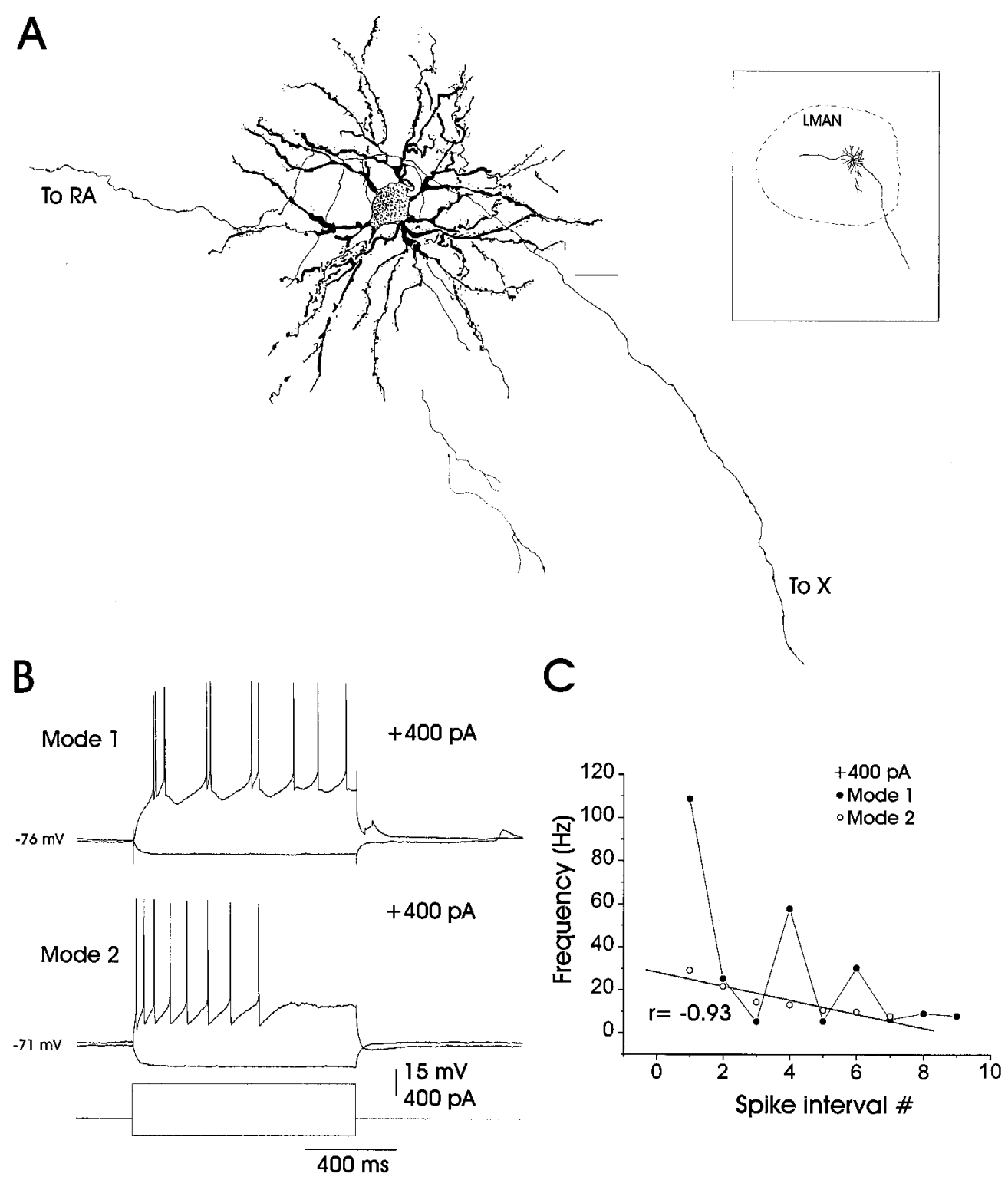

Figure 4. The morphology and sub- and suprathreshold responses of a fledgling LMAN projection neuron. $A$, Camera lucida reconstruction of a neurobiotin-stained fledgling projection neuron reveals similar morphology to adult neurons, including the spinous dendrites, local collaterals, and the bifurcating main axon with projections to area $\mathrm{X}$ and $\mathrm{RA}$. The inset on the right is a low-power camera lucida reconstruction showing the same LMAN neuron with respect to the borders of LMAN (dorsal is toward the top of the figure; rostral is toward the right). Scale bar, $20 \mu \mathrm{m} ; 200 \mu \mathrm{m}$ for inset. $B$, Fledgling LMAN projection neurons fired action potentials in two distinct modes in response to depolarizing current. In the top trace a fledgling neuron fired in a bursting manner (Mode 1) in response to depolarizing current injection. However, at a separate time during the recording session, the same neuron fired accommodating action potential trains (Mode 2) that were similar to those of adult neurons, as shown in the bottom trace. Note that the membrane potential shifted from -76 to $-71 \mathrm{mV}$ in parallel with the shift in firing modes. $C$, The instantaneous firing frequency is shown plotted as a function of the spike interval number. For cells firing in mode 2, this relationship was well fit by a straight line $[r=-0.93$; average correlation coefficient for the fledgling population, in response to $+400 \mathrm{pA}$, was $r=-0.80 \pm 0.07(n=6)]$. However, cells that fired in Mode 1 had rapidly changing instantaneous firing frequencies and were poorly fit by a straight line (fit not shown).

AMPA and NMDA receptors contribute to thalamically driven EPSPs within LMAN.

In addition to driving glutamatergic EPSPs, higher intensity thalamic fiber stimulation also evoked IPSPs within LMAN (trace 1, Fig. 9). As with evoked EPSPs, the combined EPSPIPSP was blocked by NBQX (trace 2, Fig. 9). In contrast, the $\mathrm{GABA}_{\mathrm{A}}$ receptor antagonist picrotoxin (PTX) blocked the IPSP while leaving the EPSP intact (trace 6, Fig. 9; see also Fig. 10). Because these evoked IPSPs were blocked by both NBQX and PTX, thalamic axons most likely drive feedforward inhibition via an excitatory synapse located on a GABAergic interneuron within LMAN.

\section{Developmental changes in NMDA receptor-mediated EPSCs}

Whole-cell voltage-clamp recordings were used to characterize NMDA receptor-mediated EPSCs in LMAN, because this technique permitted greater control of postsynaptic membrane potential than did sharp electrodes. This approach was necessary because NMDA EPSCs are strongly attenuated at negative 
A

Control Hyperpolarized
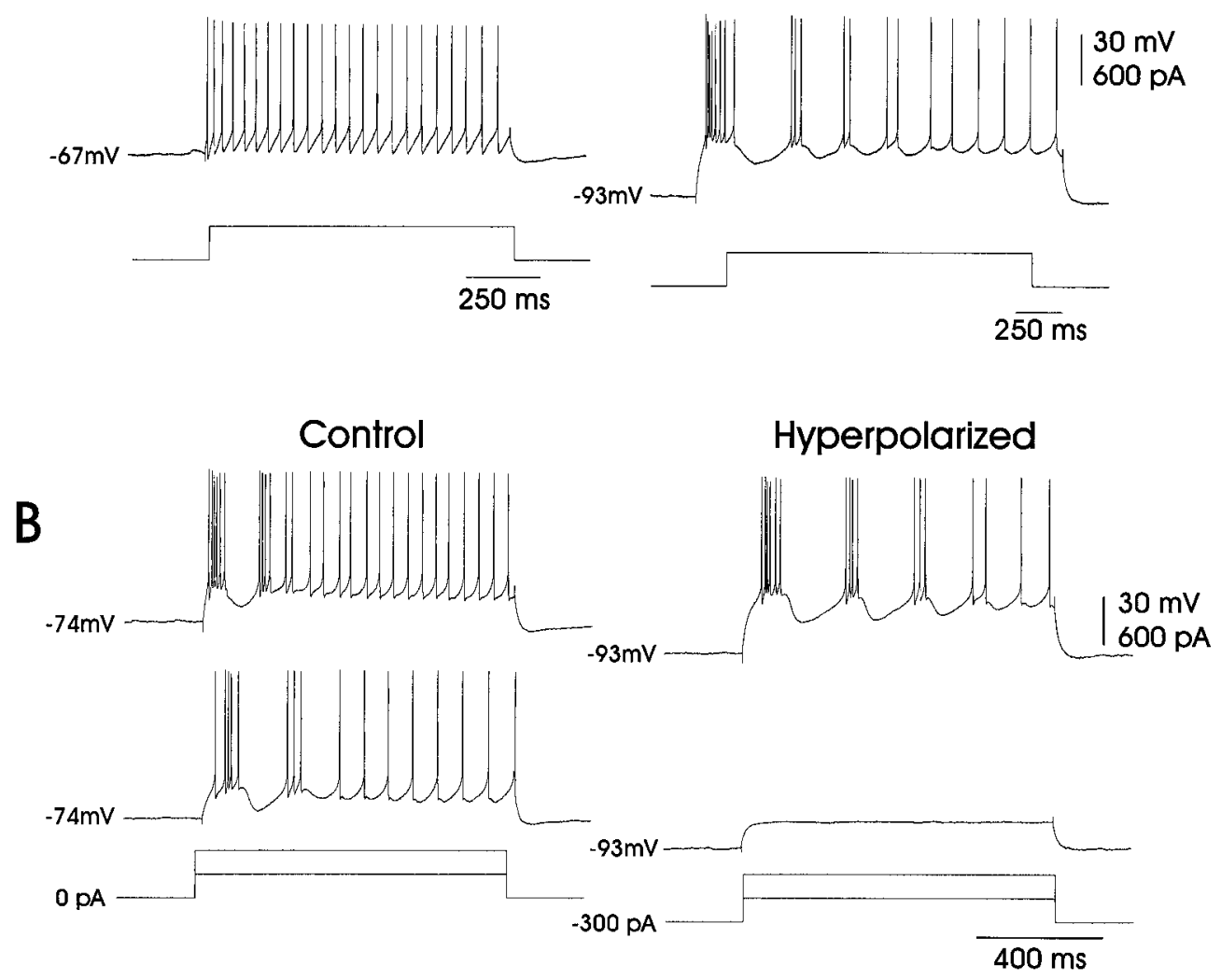

Figure 5. The effect of membrane potential on bursting in fledgling neurons. A, Hyperpolarization could unmask the bursting behavior in fledgling LMAN neurons. Initially, current injection $(+400 \mathrm{pA})$ induced only the mode 2 adult-like firing in this fledgling neuron, as shown in the left trace. However, when the membrane was subjected to tonic hyperpolarization $(-300 \mathrm{pA})$, the same depolarizing current (i.e., $+400 \mathrm{pA})$ caused the neuron to fire in mode 1, as shown in the right trace. B, Hyperpolarization also could augment preexisting bursting behavior in fledgling LMAN neurons. The two left traces show a fledgling LMAN neuron that initially fired in mode 1 in response to depolarizing currents $(+300$ and $+600 \mathrm{pA})$. When the same cell was subjected to tonic hyperpolarization $(-300 \mathrm{pA})$, as shown in the right two traces, bursting was augmented in response to the $+600 \mathrm{pA}$ current injection, although the cell remained subthreshold when injected with the $+300 \mathrm{pA}$ current.

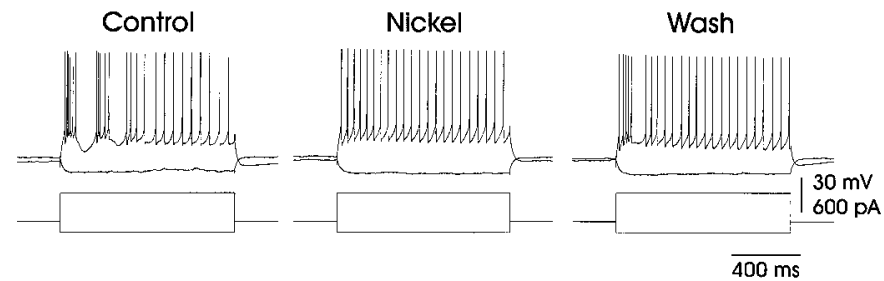

Figure 6. Mode 1 firing was blocked by extracellular application of nickel. This fledgling LMAN neuron fired in mode 1 in response to depolarizing current (left trace). Nickel $(10 \mathrm{~mm}$, applied via a puffer pipette) blocked the bursting behavior of this cell (middle trace). Sixty minutes after the nickel application the bursting behavior partially recovered (right trace). Resting potential $=-75 \mathrm{mV}$.

membrane potentials (Mayer and Westbrook, 1984; Mayer et al., 1984; Nowak et al., 1984), and LMAN neurons rest at relatively negative voltages (see Table 1). Whole-cell voltage-clamp recordings revealed that electrical stimulation of thalamic fibers could evoke both excitatory and inhibitory responses in LMAN (Fig. 10). At holding potentials between -40 and $0 \mathrm{mV}$, stimulation elicited a short-latency inward current as well as a longer-latency outward current. This longer-latency IPSC was abolished by the bath application of PTX ( $n=16 ; 4$ adult, 5 juvenile, 7 fledgling),

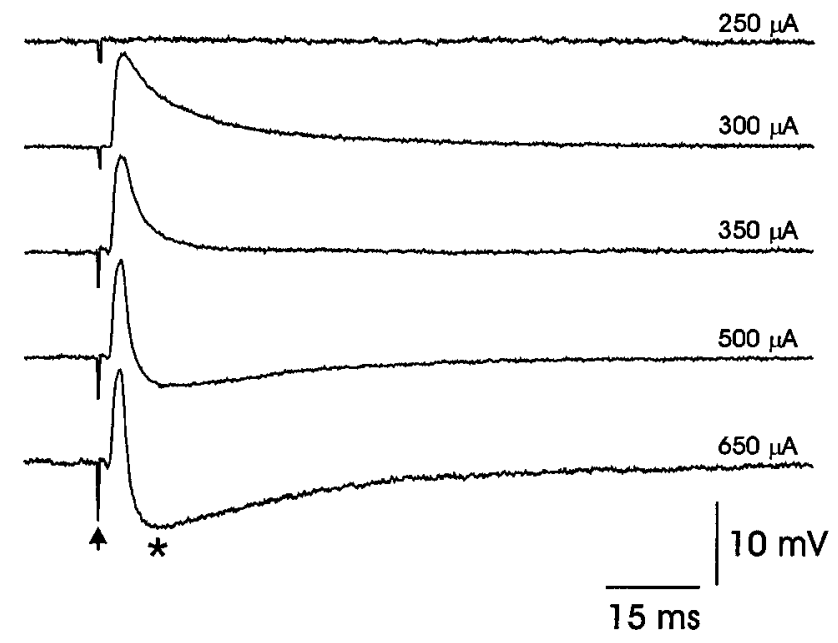

Figure 7. Excitatory and inhibitory synaptic responses could be elicited from LMAN projection neurons by electrical stimulation of DLM axons. Synaptic potentials were elicited in LMAN projection neurons in response to increasing stimulus intensities (100 $\mu \mathrm{sec}$ duration; stimulus artifact marked by arrow; the stimulus amplitude for each trace is shown on the right). At threshold $(\sim 300 \mu \mathrm{A})$ only an EPSP was elicited. At higher stimulus intensities an IPSP also was elicited (marked by asterisk). 

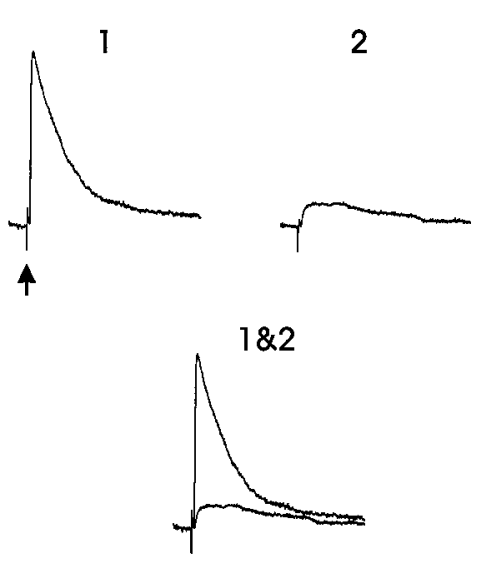

3

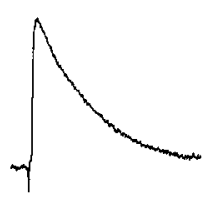

$3 \& 4$

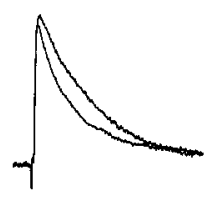

4

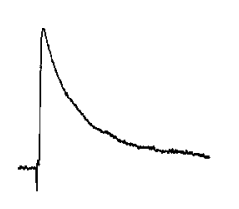

$(3-4) \& 2$

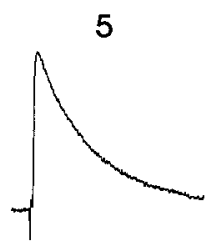

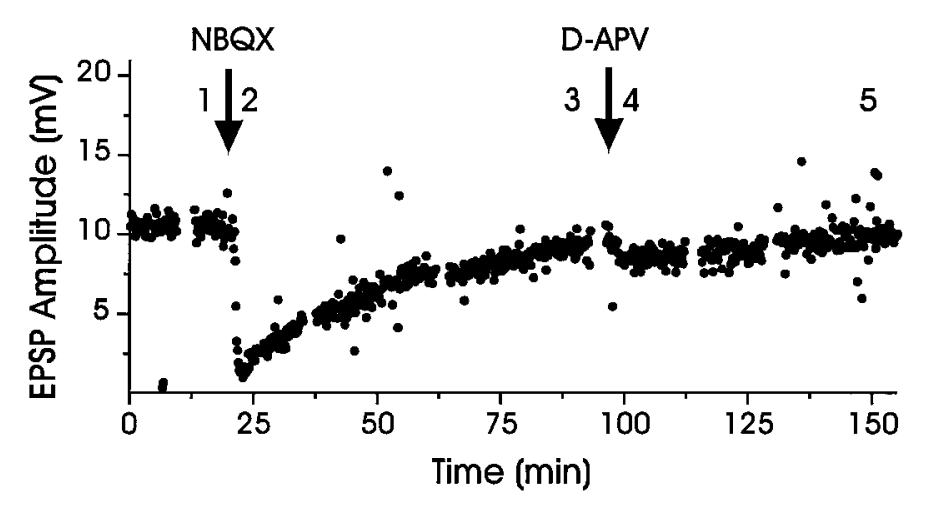

$30 \mathrm{~ms}$

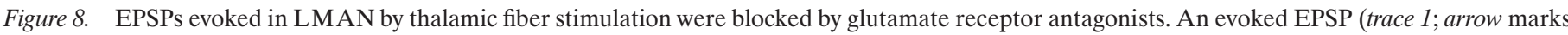

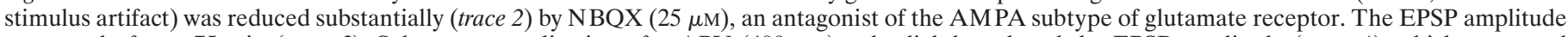

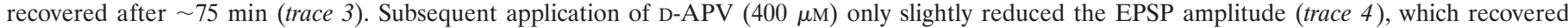

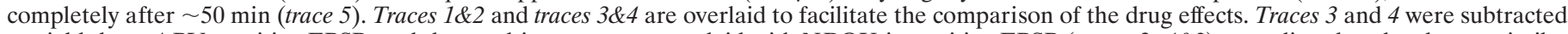

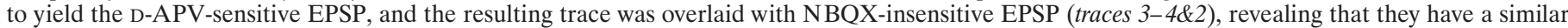

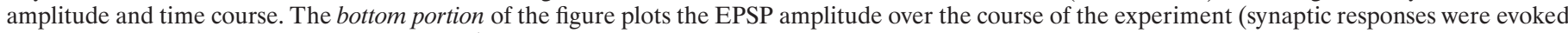
at $0.1 \mathrm{~Hz}$; mean resting potential $=-75 \mathrm{mV}$ ).

Table 2. Current-clamp synaptic properties

\begin{tabular}{|c|c|c|c|c|c|c|}
\hline $\begin{array}{l}\text { Age } \\
\text { (PHD) }\end{array}$ & $\begin{array}{l}\text { Control } \\
(\mathrm{mV} \pm \mathrm{SEM})\end{array}$ & NBQX & Recovery & Control & APV & Recovery \\
\hline \multicolumn{7}{|l|}{ Juvenile: } \\
\hline $40-51$ & $9.1 \pm 2.2, n=5$ cells & $2.4 \pm 0.6^{a}$ & $9.2 \pm 1.9$ & nd & nd & nd \\
\hline \multicolumn{7}{|l|}{ Adult: } \\
\hline $90-180$ & $9.9 \pm 1.3, n=9$ cells & $2.6 \pm 0.6^{b}$ & $8.8 \pm 1.0$ & $9.0 \pm 1.5, n=5$ cells & $7.4 \pm 1.4^{c}$ & $9.4 \pm 1.9$ \\
\hline
\end{tabular}

nd $=$ not determined.

Two-tailed $t$ tests, compared with controls: ${ }^{a} p<.001 ;{ }^{b} p<.0001 ;{ }^{c} p<.005$.

leaving only the shorter-latency inward EPSC, which was blocked by the subsequent application of NBQX ( $n=16 ; 4$ adult, 5 juvenile, 7 fledgling). Although little inward current could be detected at negative holding potentials (i.e., $-30 \mathrm{mV}$ ) in the presence of NBQX, a slower inward current could be detected in the presence of AMPA and $\mathrm{GABA}_{\mathrm{A}}$ receptor antagonists at more positive holding potentials (i.e., $0 \mathrm{mV}$; trace marked by an asterisk in Fig. 10; $n=12$ of 13 adult cells, 12 of 13 juvenile cells, and 17 of 18 fledgling cells). The negative slope conductance of the evoked EPSCs recorded within LMAN is typical of NMDA receptor-mediated EPSCs, and the attenuating effects of postsynaptic hyperpolarization indicate that NMDA receptors are located on the postsynaptic cell and not on an interposed neuron. Although these evoked EPSCs reversed positive of $0 \mathrm{mV}$ (see
Table 3), presumably because of inadequate space clamp, application of the NMDA receptor blocker D-APV reversibly abolished the evoked EPSCs that persisted in the presence of PTX and NBQX (Fig. 10; $n=4$ of 4 adult, 3 of 3 juvenile, and 3 of 3 fledgling). These recordings show that thalamic fiber stimulation can evoke NMDA receptor-mediated EPSCs within LMAN throughout song development (PHD 22-166).

Several synaptic pathways that undergo experience-dependent changes during early development also exhibit an age-dependent decrease in the duration of their NMDA receptor-mediated currents (Carmignoto and Vicini, 1992; Hestrin, 1992; Ramoa and McCormick, 1994; Crair and Malenka, 1995). To determine whether similar developmental changes occur within LMAN, we measured the NMDA component of the evoked EPSC by bathing 


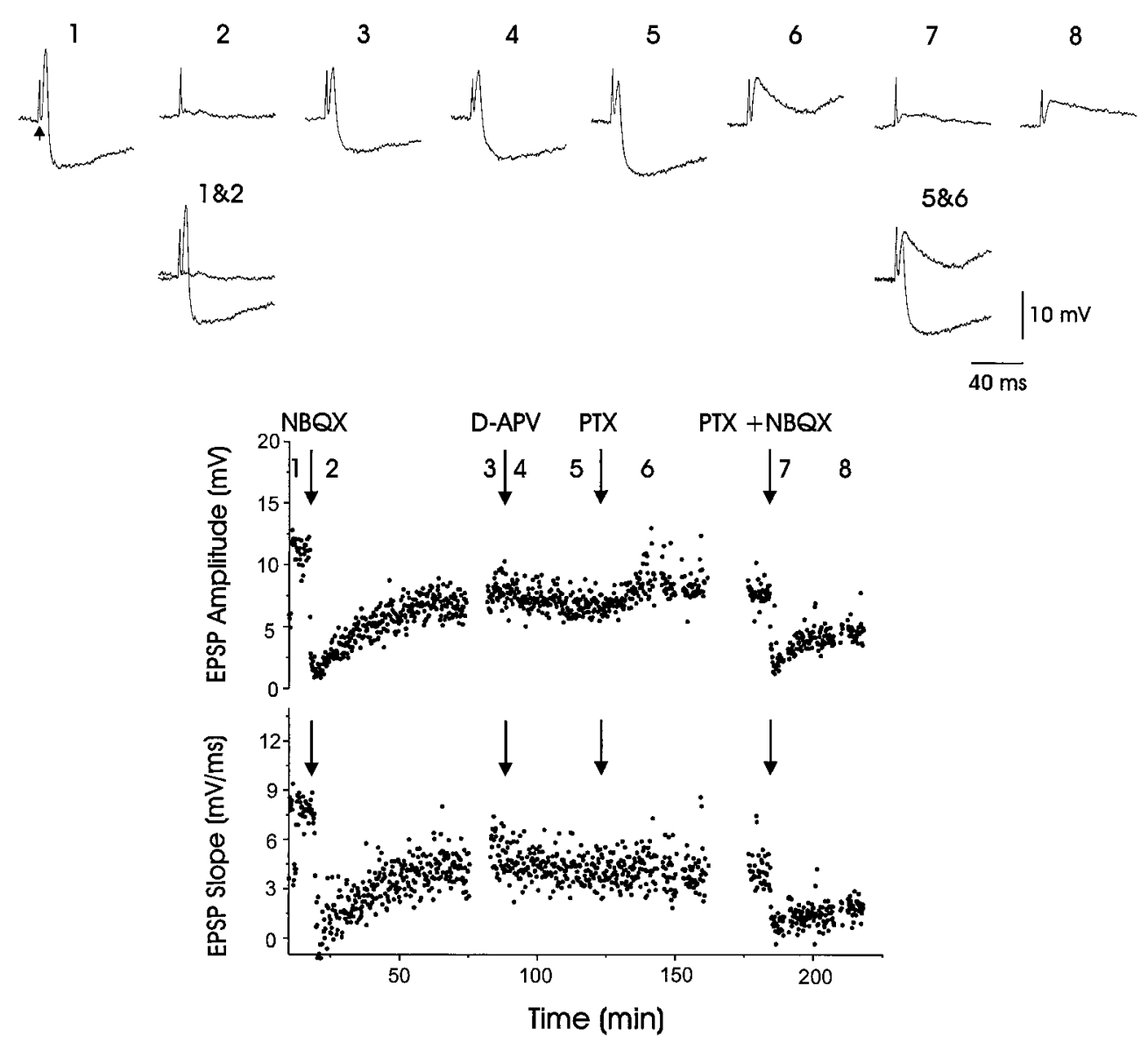

Figure 9. Both AMPA and $\mathrm{GABA}_{\mathrm{A}}$ receptor antagonists blocked IPSPs elicited in LMAN by electrical stimulation of thalamic axons. An evoked compound EPSP-IPSP (trace 1; arrow marks stimulus artifact) was blocked (trace 2) by NBQX (25 $\mu \mathrm{M})$; the compound response partially recovered after $\sim 50$ min (trace 3). In contrast, the application of D-APV $(800 \mu \mathrm{M})$ had no effect on either the EPSP or the IPSP (traces 4 and 5$)$. The application of picrotoxin $(P T X ; 200 \mu \mathrm{M})$ selectively eliminated the IPSP, leaving only the EPSP (trace 6$)$. The remaining EPSP was reduced substantially by the application of NBQX $(25 \mu \mathrm{M}$; trace 7), followed by a partial recovery (trace 8). Traces $1 \& 2$ and traces $5 \& 6$ are overlaid to facilitate comparison of the drug effects. The bottom two portions of the figure plot the PSP amplitude and onset slope over the course of the experiment (synaptic responses were elicited every $10 \mathrm{sec}$; average resting potential $=-79 \mathrm{mV}$ )

the slice in NBQX $(2.5 \mu \mathrm{M})$ and PTX $(50 \mu \mathrm{M})$ while holding the postsynaptic membrane $20 \mathrm{mV}$ positive of the reversal potential to relieve voltage-dependent block by extracellular magnesium. In these conditions evoked EPSCs at all ages were well fit with a double-exponential function, yielding a fast and a slow decay time constant (Fig. 11A, Table 3). These analyses show that the slow component constituted a significantly larger fraction of the total current in fledgling neurons than it did in juvenile and adult neurons (Fig. 11 $A, B$, Table 3 ) and that the transition to the faster decay kinetics is complete in large part by PHD 40 (Fig. 11B). This difference in decay kinetics was apparent although the actual values of the two time constants remained constant throughout development (Fig. 11C, Table 3). In contrast to the change in decay kinetics, neither EPSC rise times nor input resistances changed significantly during development (Table 3), strengthening the hypothesis that the observed differences in decay kinetics are attributable to underlying differences in NMDA receptor properties. These results show that the decay kinetics of NMDA receptor-mediated EPSCs evoked within LMAN change markedly over the course of early song development (PHD 32-40).

\section{DISCUSSION}

This study shows that LMAN neurons undergo distinct changes in their intrinsic and synaptic electrophysiological properties be-

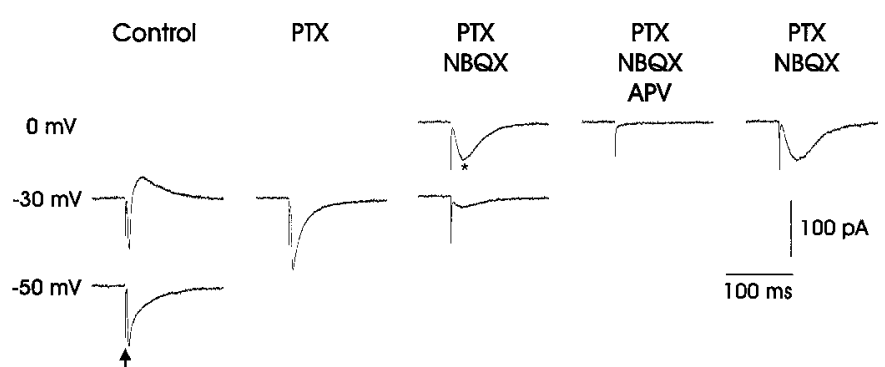

Figure 10. Whole-cell voltage-clamp recordings (holding potential specified to the left) showed that thalamic fiber stimulation (marked by arrow in bottom left trace) could evoke glutamatergic EPSCs that were blocked by the AMPA receptor antagonist NBQX, GABAergic IPSCs, and voltage-dependent NMDA receptor-mediated EPSCs from LMAN neurons. At $V_{\mathrm{h}}=-30 \mathrm{mV}$ (relative to $E_{\mathrm{rev}}$; see Materials and Methods), the evoked EPSC was inward-going, whereas the IPSC was outward. The $\mathrm{GABA}_{\mathrm{A}}$ receptor blocker picrotoxin $(P T X ; 50 \mu \mathrm{M})$ blocked the IPSC, leaving a fast inward current that was blocked by the AMPA receptor antagonist NBQX $(2.5 \mu \mathrm{M})$. The remaining slower inward current, which increased in amplitude when the cell was held at $0 \mathrm{mV}$, was blocked by the NMDA receptor antagonist D-APV $\left(\begin{array}{lll}50 & \mu \mathrm{M}\end{array}\right)$. In LMAN, NMDA receptor-mediated EPSCs reversed positive of $0 \mathrm{mV}$ (see Table 3), suggesting that the synaptic membrane was more negative than the reported values because of incomplete space clamp. 
Table 3. Properties of NMDA receptor-mediated EPSCs $\left(V_{\mathrm{h}}=+20 \mathrm{mV}\right.$, relative to $\left.E_{\text {rev }}\right)$

\begin{tabular}{|c|c|c|c|}
\hline Parameter & $\begin{array}{l}\text { Fledgling: } 22-32 \text { PHD } \\
\text { (mean }=28, n=9 \text { cells } \\
\text { from } 9 \text { slices })\end{array}$ & $\begin{array}{l}\text { Juvenile: } 40-51 \text { PHD } \\
\text { (mean }=44, n=8 \text { cells } \\
\text { from } 8 \text { slices })\end{array}$ & $\begin{array}{l}\text { Adult: } 90-180 \\
\text { PHD (mean }=136, \\
n=8 \text { cells from } 8 \\
\text { slices) }\end{array}$ \\
\hline Amplitude $(\mathrm{pA} \pm \mathrm{SEM})^{a}$ & $85 \pm 13$ & $123 \pm 45$ & $70 \pm 13$ \\
\hline Decay $\tau_{1}(\mathrm{msec} \pm \mathrm{SEM})^{b}$ & $42 \pm 6$ & $39 \pm 4$ & $32 \pm 2$ \\
\hline Decay $\tau_{2}(\mathrm{msec} \pm \mathrm{SEM})^{c}$ & $197 \pm 24$ & $208 \pm 38$ & $177 \pm 16$ \\
\hline \multicolumn{4}{|l|}{ Slow component $(\%)(((\mathrm{A} 2 /(\mathrm{A} 1+$} \\
\hline $\mathrm{A} 2)) \cdot 100) \pm \mathrm{SEM})^{d *}$ & $50 \pm 05$ & $28 \pm 04$ & $20 \pm 04$ \\
\hline $10-90 \%$ rise time $(\mathrm{msec} \pm \mathrm{SEM})^{e}$ & $6.5 \pm 0.4$ & $6.4 \pm 1.1$ & $4.8 \pm 0.4$ \\
\hline Input resistance $(\mathrm{M} \Omega \pm \mathrm{SEM})^{f}$ & $102 \pm 16$ & $98 \pm 11$ & $93 \pm 11$ \\
\hline$E_{\mathrm{rev}}(\mathrm{mV} \pm \mathrm{SEM})^{g, h}$ & $54 \pm 6$ & $49 \pm 8$ & $52 \pm 4$ \\
\hline
\end{tabular}

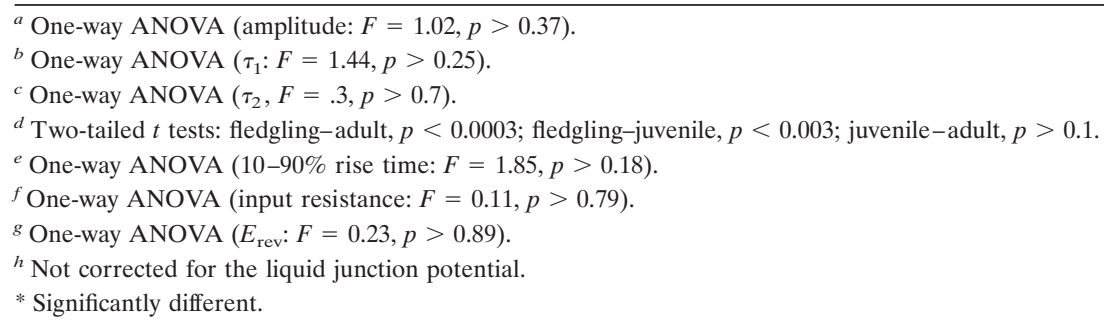

tween the fledgling and juvenile stages of life (PHD 32-40). LMAN projection neurons in fledgling zebra finches can display two modes of action potential firing, including a bursting mode that is not expressed in the same class of neurons in the juvenile and adult. In addition, the decay kinetics of NMDA receptormediated EPSCs in LMAN become markedly faster between PHD 32-40. The time course of these changes contrasts with our original hypothesis that such physiological changes should extend into later sensorimotor learning (i.e., PHD 50-90). Therefore, if such changes are pertinent to song development, they must relate to earlier events, such as sensory acquisition and the initial stages of sensorimotor learning, rather than later periods of vocal plasticity and the process of song crystallization.

Intracellular neurobiotin staining revealed that the recordings made here are from LMAN projection neurons. These cells have axon branches that project toward area $\mathrm{X}$ and nucleus $\mathrm{RA}$, consistent with anatomical tracing experiments that show that many individual LMAN neurons project to both targets (Nixdorf-Bergweiler et al., 1995a; Vates and Nottebohm, 1995). In addition, these neurons have radially symmetric spinous dendrites and are thus likely to be the same class as those spinous cells identified in Golgi studies that undergo an age-dependent decrease in spine frequency (Nixdorf-Bergweiler et al., 1995b). A preliminary analysis of the morphology of LMAN projection neurons labeled here indicates that, although they undergo a similar developmental decrease in spine frequency, the overall extent of their dendritic arbors is remarkably constant across these ages (Stacy et al., 1997).

Despite their similar dendritic morphologies, resting potentials, and input resistances, adult and fledgling LMAN projection neurons differed markedly in their suprathreshold responses to depolarizing currents. Adult neurons fired trains of action potentials in response to depolarization that accommodated over the duration of the injected current pulse. This accommodation was characterized by a linear relationship between the instantaneous spike frequency and the spike interval number. In contrast, fledgling neurons displayed a burst mode of firing in response to similar depolarizing currents (mode 1 ) as well as in some in- stances firing in an adult-like manner. The two modes of firing exhibited by fledgling LMAN neurons are thought to reflect the behavior of a single cell class because (1) two cells spontaneously switched from mode 2 to mode 1 during the recording (see, for example, Fig. 4B), (2) four cells that initially exhibited the linear mode could be induced to burst by previous hyperpolarization (Fig. 5A), and (3) the morphologies of cells displaying either or both firing modes were those of LMAN projection neurons.

Mode 1 firing is reminiscent of several other forms of burst firing, including that described for adult X-projecting $\mathrm{HVc}$ neurons (Kubota and Saito, 1991), mammalian thalamic neurons (Jahnsen and Llinás, 1984), and neocortical pyramidal neurons (Silva et al., 1991; Gray and McCormick, 1996). As in these other cell types, the mode 1 firing of fledgling LMAN neurons involves a putative LTS, because it is blocked by nickel (Fox et al., 1987) and augmented by previous hyperpolarization. Modulatory factors that can elicit hyperpolarization, such as norepinephrine, have been shown to augment LTS-dependent bursting in the mammalian thalamus (McCormick, 1989). In the song system, tyrosine hydroxylase, an enzyme essential to catecholamine production, as well as certain adrenergic receptors, has been localized to LMAN (Bottjer, 1993; Ball, 1994; Soha et al., 1996). Further studies will be required to determine whether norepinephrine or other modulatory factors influence bursting in fledgling LMAN neurons.

In the zebra finch, bursting correlates both with sensory acquisition, which can be complete as early as PHD 35 (Bohner, 1990), and early sensorimotor learning, which begins between PHD 28-40 (Immelmann, 1969; Arnold, 1975). Burst firing in presynaptic cells has been shown to increase the probability of eliciting a postsynaptic response (Miles and Wong, 1986; Stevens and Wang, 1995). In LMAN, this mechanism might facilitate auditory responses to the tutor song during sensory acquisition or augment signaling to RA during early sensorimotor learning. However, the bursting behavior disappears before the time when LMAN lesions fail to disrupt song development and well before sensorimotor learning is complete (Bottjer et al., 1984; Scharff and 
A
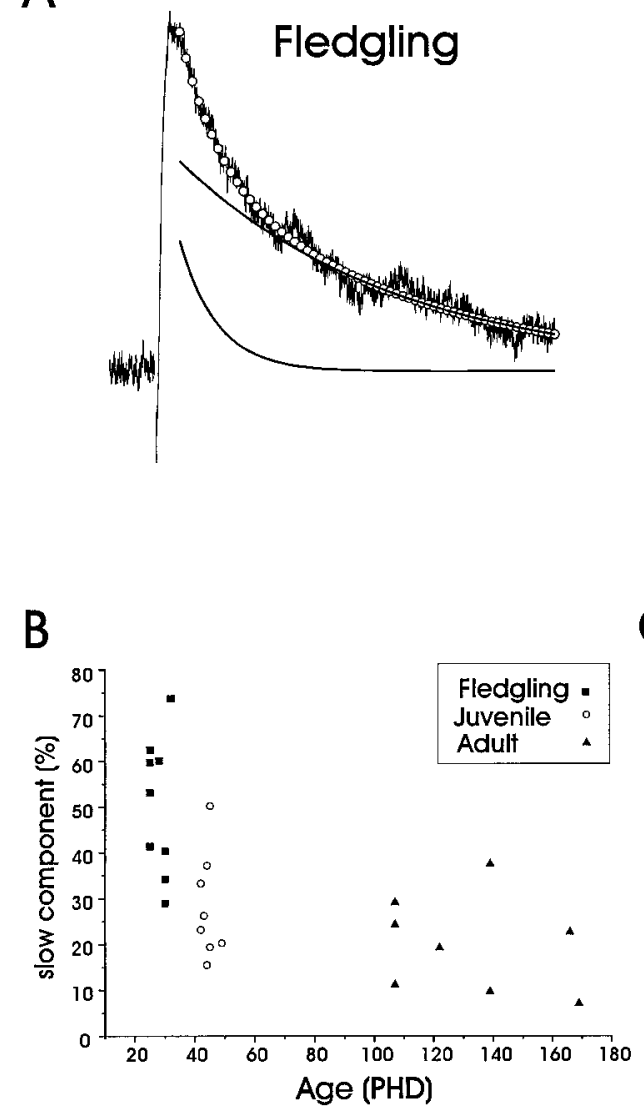
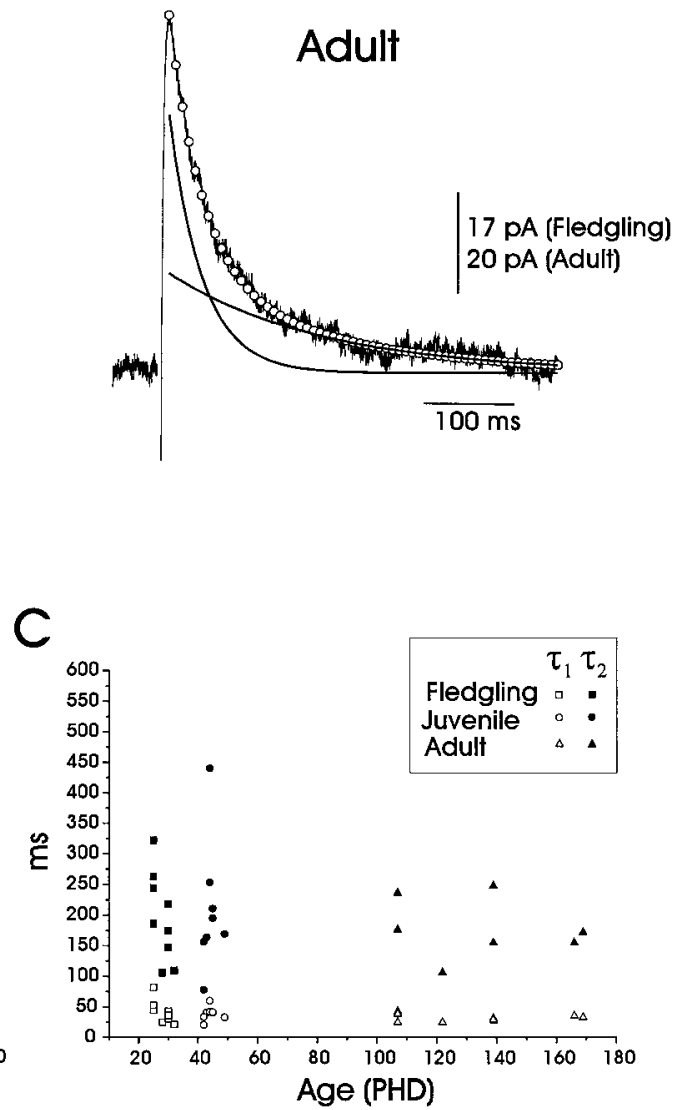

Figure 11. The decay kinetics of NMDA receptor-mediated EPSCs elicited in LMAN by thalamic fiber stimulation change during early development. $A$, On the left is an evoked NMDA receptor EPSC from a fledgling LMAN projection neuron, and on the right is a NMDA receptor EPSC from that of an adult. These NMDA receptor-mediated EPSCs were best fit by double exponentials, which are represented by the open circles. The black curves represent the fast $\left(\tau_{1}\right)$ and slow $\left(\tau_{2}\right)$ exponentials that constitute the double-exponential fit (fledgling: $\tau_{1}=45 \mathrm{msec}, \tau_{2}=245 \mathrm{msec}, \mathrm{A}_{1}=17$, and $\mathrm{A}_{2}$ $=25.1$; adult: $\tau_{1}=38 \mathrm{msec}, \tau_{2}=175 \mathrm{msec}, \mathrm{A}_{1}=45.3$, and $\mathrm{A}_{2}=18.6$; see Materials and Methods). The slow component constituted a significantly larger fraction of the total synaptic current in the fledgling than in either the juvenile or adult [EPSCs were recorded in the presence of NBQX (2.5 $\mu \mathrm{M})$ and picrotoxin $(50 \mu \mathrm{M})$ at $V_{\mathrm{h}}=+20 \mathrm{mV}$ of $\left.E_{\mathrm{rev}}\right] . B$, The percentage of the falling phase of the total response amplitude constituted by the slow component of the double-exponential fit declined with age $\left[\left(\mathrm{A}_{2} /\left(\mathrm{A}_{1}+\mathrm{A}_{2}\right) \cdot 100\right.\right.$; see Materials and Methods and Table 3 for further details]. $C$, Fast and slow time constants $\left(\tau_{1}\right.$ and $\left.\tau_{2}\right)$ from the double-exponential fits did not change significantly as a function of age (see Materials and Methods and Table 3 for further details).

Nottebohm, 1991), arguing against its role in the later stages of plastic song.

This study provides the first characterization of synaptic transmission within nucleus LMAN and shows that synapses between DLM and LMAN are functional by PHD 22. DLM axons evoke excitatory synaptic responses from LMAN projection neurons and also activate a feedforward inhibitory pathway within LMAN (also see Boettiger and Doupe, 1996). This excitatory drive is mediated by a combination of AMPA and NMDA receptors located on LMAN projection neurons, whereas the inhibitory drive is mediated by a GABAergic synapse, because it is blocked by the $\mathrm{GABA}_{\mathrm{A}}$ receptor blocker picrotoxin. Inhibition is likely to be polysynaptic because it is also blocked by application of AMPA receptor antagonists, contrary to the expected effect if thalamic axons made direct inhibitory contacts onto LMAN projection neurons. The most parsimonious explanation is that DLM axons activate AMPA receptors located on GABAergic interneurons within LMAN.

DLM axons directly activate NMDA receptors located on LMAN projection neurons. The identification of inputs that activate NMDA receptors within LMAN is specifically relevant, because the infusion of NMDA receptor antagonists into the neostriatal region (which includes LMAN) of young zebra finches during tutoring disrupts subsequent song development (Basham et al., 1996) and because NMDA receptor density within LMAN declines with maturation (Aamodt et al., 1992; Basham, 1996). Therefore, a major site where NMDA receptor antagonists could disrupt song development is at the synapse between DLM axons and LMAN projection neurons.

The decay kinetics of NMDA receptor-mediated EPSCs in LMAN become markedly faster over development. These changes could reflect developmental differences in the relative composition of the receptor population, changes in the kinetics of individual NMDA receptors, the disproportionate loss of NMDA receptors from distal processes, or changes in postsynaptic filtering of synaptic currents. These latter two factors are unlikely to be significant because the developmental loss of dendritic spines (a major location of NMDA receptors; see Connor et al., 1994; Petralia et al., 1994) on LMAN neurons does not appear to selectively involve distal processes (Nixdorf-Bergweiler et al., 1995b). Also, unlike the change in decay kinetics, the rise times of these EPSCs do not change significantly during development, 
which contrasts with the expected effects of altered dendritic filtering (Spruston et al., 1994). Therefore, NMDA receptormediated currents could become faster because of changes in individual receptors (Monyer et al., 1992), perhaps because of differential expression of NMDA receptor subunits, as has been described in the developing mammalian brain (Williams et al., 1993; Monyer et al., 1994). In support of this view, ifenprodil, which binds with high affinity to NMDA receptor heteromultimers containing the NR2B subunit, has been shown to bind at significantly greater levels in the LMAN of PHD 30 male zebra finches relative to adults (Basham et al., 1997).

Developmental changes in the time course of NMDA receptormediated currents occur at several central synapses that undergo activity-dependent development. At mammalian retinocollicular and thalamocortical synapses, NMDA receptor-mediated EPSCs become more rapid as sensitive periods for activity-dependent remodeling come to a close (Carmignoto and Vicini, 1992; Hestrin, 1992; Ramoa and McCormick, 1994; Crair and Malenka, 1995). In the zebra finch the change in NMDA receptor kinetics in LMAN occurs between PHD 30-40, which is a pivotal time for synaptic remodeling in LMAN. Golgi studies indicate that LMAN neurons undergo a significant increase in spine frequency between PHD 21-35 and then decline gradually to adult levels thereafter (Nixdorf-Bergweiler et al., 1995b). Our data show that slower NMDA decay kinetics are present during the early increase in dendritic spine frequency and that faster kinetics correlate with the period of spine frequency reduction in LMAN. When zebra finches are raised in acoustical isolation, the decrease in spine frequency fails to occur (Wallhausser-Franke et al., 1995), and the period of sensory acquisition is extended (Eales, 1985; Morrison and Nottebohm, 1993). If these different NMDA EPSC phenotypes facilitate dendritic remodeling in LMAN, then acoustical isolation should delay the transition from fledgling to adult NMDA receptor decay kinetics just as the change in spine frequency is halted. Finally, if the slower currents typical of fledgling LMAN neurons are specifically required for synaptic changes during song learning, then their role must be limited to early events, such as sensory acquisition and the onset of sensorimotor learning, but not to the later stages of plastic song, including crystallization.

\section{REFERENCES}

Aamodt SM, Kozlowski MR, Nordeen EJ, Nordeen KW (1992) Distribution and developmental change in $\left[{ }^{3} \mathrm{H}\right] \mathrm{MK}-801$ binding within zebra finch song nuclei. J Neurobiol 23:997-1005.

Arnold AP (1975) The effects of castration on song development in zebra finches (Poephila guttata). J Exp Zool 191:261-278.

Ball GF (1994) Neurochemical specializations associated with vocal learning and production in songbirds and budgerigars. Brain Behav Evol 44:234-246.

Basham ME (1996) Developmental regulation of mRNA for the NMDAR1 subunit in zebra finches. Soc Neurosci Abstr 22:692.

Basham ME, Nordeen EJ, Nordeen KW (1996) Blockade of NMDA receptors in the anterior forebrain impairs sensory acquisition in the zebra finch (Poephila guttata). Neurobiol Learn Mem 66:295-304.

Basham ME, Nordeen EJ, Nordeen KW (1997) Developmental regulation of NMDA2B receptor binding in the zebra finch anterior forebrain. Soc Neurosci Abstr 23:797.

Boettiger CA, Doupe AJ (1996) Intracellular characterization of electrophysiologic properties and synaptic responses in the zebra finch song nucleus LMAN. Soc Neurosci Abstr 22:153.

Bohner J (1990) Early acquisition of song in the zebra finch, Taeniopygia guttata. Anim Behav 39:369-374.

Bottjer SW (1993) The distribution of tyrosine hydroxylase immunore- activity in the brains of male and female zebra finches. J Neurobiol 24:51-69.

Bottjer SW, Miesner EA, Arnold AP (1984) Forebrain lesions disrupt development but not maintenance of song in passerine birds. Science 224:901-903.

Bottjer SW, Halsema KA, Brown SA, Miesner EA (1989) Axonal connections of a forebrain nucleus involved with vocal learning in zebra finches. J Comp Neurol 279:312-326.

Carmignoto G, Vicini S (1992) Activity-dependent decrease in NMDA receptor responses during development of the visual cortex. Science 258:1007-1011.

Connor JA, Miller LD, Petrozzino J, Muller W (1994) Calcium signaling in dendritic spines of hippocampal neurons. J Neurobiol 25:234-242.

Crair MR, Malenka RC (1995) A critical period for long-term potentiation at thalamocortical synapses. Nature 375:325-328.

Eales LA (1985) Song learning in zebra finches: some effects of song model availability on what is learnt and when. Anim Behav 33:1293-1300.

Fox AP, Nowycky MC, Tsien RW (1987) Kinetic and pharmacological properties distinguishing three types of calcium currents in chick sensory neurones. J Physiol (Lond) 394:149-172.

Gray CM, McCormick DA (1996) Chattering cells: superficial pyramidal neurons contributing to the generation of synchronous oscillations in the visual cortex. Science 274:109-113.

Hestrin S (1992) Developmental regulation of NMDA receptormediated synaptic currents at a central synapse. Nature 357:686-689.

Immelmann K (1969) Song development in zebra finch and other Estrildid finches. In: Bird vocalisations (Hinde RA, ed), pp 61-74. London: Cambridge UP.

Jahnsen H, Llinás R (1984) Electrophysiological properties of guineapig thalamic neurones: an in vitro study. J Physiol (Lond) 349:205-226.

Konishi M (1965) The role of auditory feedback in the control of vocalization in the white-crowned sparrow. Z Tierpsychol 22:770-783.

Kubota M, Saito N (1991) Sodium- and calcium-dependent conductances of neurones in the zebra finch hyperstriatum ventrale pars caudale in vitro. J Physiol (Lond) 440:131-142.

Mayer ML, Westbrook GL (1984) Mixed-agonist action of excitatory amino acids on mouse spinal cord neurones under voltage clamp. J Physiol (Lond) 354:29-53.

Mayer ML, Westbrook GL, Guthrie PB (1984) Voltage-dependent block by $\mathrm{Mg}^{2+}$ of NMDA responses in spinal cord neurones. Nature 309:261-263.

McCasland JS (1987) Neuronal control of birdsong production. J Neurosci 7:23-39.

McCormick DA (1989) Cholinergic and noradrenergic modulation of thalamocortical processing. Trends Neurosci 12:215-221.

Miles R, Wong RK (1986) Excitatory synaptic interactions between CA3 neurones in the guinea-pig hippocampus. J Physiol (Lond) 373:397-418.

Monyer H, Sprengel R, Schoepfer R, Herb A, Higuchi M, Lomeli H, Burnashev N, Sakmann B, Seeburg PH (1992) Heteromeric NMDA receptors: molecular and functional distinction of subtypes. Science 256:1217-1221.

Monyer H, Burnashev N, Laurie DJ, Sakmann B, Seeburg PH (1994) Developmental and regional expression in the rat brain and functional properties of four NMDA receptors. Neuron 12:529-540.

Mooney R, Konishi M (1991) Two distinct inputs to an avian song nucleus activate different glutamate receptor subtypes on individual neurons. Proc Natl Acad Sci USA 88:4075-4079.

Morrison RG, Nottebohm F (1993) Role of a telencephalic nucleus in the delayed song learning of socially isolated zebra finches. J Neurobiol 24:1045-1064.

Nixdorf-Bergweiler BE, Lips MB, Heinemann U (1995a) Electrophysiological and morphological evidence for a new projection of LMANneurones towards area X. NeuroReport 6:1729-1732.

Nixdorf-Bergweiler BE, Wallhausser-Franke E, DeVoogd TJ (1995b) Regressive development in neuronal structure during song learning in birds. J Neurobiol 27:204-215.

Nottebohm F, Stokes TM, Leonard CM (1976) Central control of song in the canary, Serinus canarius. J Comp Neurol 165:457-486.

Nottebohm F, Kelley DB, Paton JA (1982) Connections of vocal control nuclei in the canary telencephalon. J Comp Neurol 207:344-357.

Nowak L, Bregestovski P, Ascher P, Herbet A, Prochiantz A (1984) Magnesium gates glutamate-activated channels in mouse central neurones. Nature 307:462-465. 
Okuhata S, Saito N (1987) Synaptic connections of a forebrain nucleus involved with vocal learning in zebra finches. Brain Res Bull 18:35-44.

Petralia RS, Yokotani N, Wenthold RJ (1994) Light and electron microscope distribution of the NMDA receptor subunit NMDAR1 in the rat nervous system using a selective anti-peptide antibody. J Neurosci 14:667-696.

Price PH (1979) Developmental determinants of structure in zebra finch song. J Comp Physiol Psychol 93:260-277.

Ramoa AS, McCormick DA (1994) Enhanced activation of NMDA receptor responses at the immature retinogeniculate synapse. J Neurosci 14:2098-2105.

Scharff C, Nottebohm F (1991) A comparative study of the behavioral deficits following lesions of various parts of the zebra finch song system: implications for vocal learning. J Neurosci 11:2896-2913.

Silva LR, Amitai Y, Connors BW (1991) Intrinsic oscillation of neocortex generated by layer 5 pyramidal neurons. Science 251:432-435.

Simpson HB, Vicario DS (1990) Brain pathways for learned and unlearned vocalizations differ in zebra finches. J Neurosci 10:1541-1556.

Slater PJB, Eales LA, Clayton NS (1988) Song learning in zebra finches (Taeniopygia guttata): progress and prospects. Adv Study Behav 18:1-34.

Soha JA, Shimizu T, Doupe AJ (1996) Development of the cat- echolaminergic innervation of the song system of the male zebra finch. J Neurobiol 29:473-489.

Spruston N, Jaffe DB, Johnston D (1994) Dendritic attenuation of synaptic potentials and currents: the role of passive membrane properties. Trends Neurosci 17:161-166.

Stacy RC, Livingston FS, Spiro JE, Mooney R (1997) Developmental changes in song system neuron morphology as revealed by intracellular staining in brain slices. Soc Neurosci Abstr 23:245.

Stevens CF, Wang Y (1995) Facilitation and depression at single central synapses. Neuron 14:795-802.

Vates GE, Nottebohm F (1995) Feedback circuitry within a songlearning pathway. Proc Natl Acad Sci USA 92:5139-5143.

Wallhausser-Franke E, Nixdorf-Bergweiler BE, DeVoogd TJ (1995) Song isolation is associated with maintaining high spine frequencies on zebra finch LMAN neurons. Neurobiol Learn Mem 64:25-35.

Wild JM (1993) Descending projections of the songbird nucleus robustus archistriatalis. J Comp Neurol 338:225-241.

Williams K, Russell SL, Shen YM, Molinoff PB (1993) Developmental switch in the expression of NMDA receptors occurs in vivo and in vitro. Neuron 10:267-278.

Yu AC, Dave AS, Margoliash D (1996) Temporal hierarchical control of singing in birds. Science 273:1871-1875. 